Doetsch, R. N., Howard, B. H., Mann, S. O. \& Oxford, A. E. (1957). J. gen. Microbiol. 16, 156-168

\title{
Physiological Factors in the Production of an Iodophilic Polysaccharide from Pentose by a Sheep Rumen Bacterium
}

\author{
By R. N. DOETSCH, B. H. HOWARD, S. O. MANN \\ AND A. E. OXFORD \\ The Rowett Research Institute, Bucksburn, Aberdeenshire, Scotland
}

SUMMARY: A Gram-negative, non-flagellated, asporogenous, anaerobic, iodophilic, curved rod $\left(2.5 \mu_{0} \times 0.5 \mu\right.$.) was isolated from the rumen of a sheep and designated Bacteroides amylogenes n.sp. This organism transforms a number of carbohydrates including pentoses to intracellular iodophilic polysaccharide which has been isolated and shown to be a polymer of glucose. Resting suspensions of this organism utilize this iodophilic material as a reserve substance under a variety of conditions. Bacteroides amylogenes grows optimally in vitro when bicarbonate and rumen liquor are included in the medium. On physiological and morphological grounds it is considered to be an authentic rumen bacterium. The chief fermentation product from xylose is butyric acid.

Recent investigations by Robinson, Doetsch, Sirotnak \& Shaw (1955), Mann \& Oxford (1955), Gibbons, Doetsch \& Shaw (1955), and Hobson \& Mann (1955) revealed that authentic rumen bacteria may produce intracellular iodophilic polysaccharide from carbohydrate substrates. Earlier references dealing with 'starch' or 'glycogen' formation in bacteria of avian or mammalian intestines are given in Hobson \& Mann (1955). Heretofore there has been but one report concerning iodophilic polysaccharide formation from $\mathrm{D}(+)$ xylose by mixed suspensions of bovine rumen bacteria (Gibbons et al. 1955). It was shown that a polysaccharide 'ISS' (an abbreviation for iodine staining substance), composed solely of glucose, was produced from either $\mathbf{D}(+)$ glucose or $\mathbf{D}(+)$ xylose by a mixed rumen bacterial flora, irrespective of the number of different 'species' that might be present.

The present paper studies the physiological factors which govern this interesting polymerization phenomenon when a pure culture of a Gramnegative sheep rumen bacterium, not previously described, is used. In view of this, morphological, physiological and nutritional data are given for taxonomic characterization of the organism. Although on morphological grounds alone (see organism no. 9 (fig. 21) of Moir \& Masson, 1952, which resembles it) it may well be a rumen bacterium, the authenticity of this isolate is judged mainly in the physiological sense, i.e. it is obligately anaerobic; grows only over a narrow temperature range near $39^{\circ}$; requires a factor(s) found in rumen liquor for optimal in vitro growth; and forms ISS and end products normally associated with rumen liquor. 


\section{METHODS}

\section{Isolation of xylose-fermenting bacteria}

Rumen liquor samples were obtained from fistulated sheep no. 879 (Eadie \& Oxford, 1955). This animal was fed $750 \mathrm{~g}$. hay and $450 \mathrm{~g}$. concentrates/day. Rumen liquor samples were taken $c .3 \mathrm{hr}$. after morning feeding. The culture technique of Hungate (1950) was used, but with the dilution blanks devised by Doetsch, Robinson \& Shaw (1952). $\mathrm{D}(+)$ Xylose (substituted for $\mathbf{D}(+)$ glucose and cellobiose) cysteine hydrochloride and $\mathrm{Na}_{2} \mathrm{CO}_{3}$ were sterilized together by Seitz filtration and added aseptically to the autoclaved rumen liquor + mineral salts agar to give final concentrations $(\mathrm{w} / \mathrm{v})$ of $1,0 \cdot 1$ and $0 \cdot 4 \%$, respectively. Roll tubes were incubated at $39^{\circ}$ and colonies selected from $10^{-7}$ or $10^{-8}$ dilutions after $48-72 \mathrm{hr}$. Colonies were subcultured only when microscopic examination of a wet mount stained with Lugol's iodine solution revealed a purple or blue coloration within the cells (Hobson \& Mann, 1955). One isolate $(4 \cdot 13)$ was selected from a collection of xylose-fermenting rumen bacteria for intensive study. Conventional pure culture techniques were used for Gram's staining method, capsule stain, granule stain, indole, $\mathrm{H}_{2} \mathrm{~S}$ and catalase production, and optimum growth temperature. Motility determinations were made in sealed capillary tubes, and flagella stains were made by the methods of Fisher \& Conn (1942), Leifson (1951) and Plimmer \& Paine (1921).

\section{Range of compounds transformed to iodophilic polysaccharide}

Most of the compounds studied (Table 1) were sterilized by Seitz filtration and substituted in final concentration of $1 \%(\mathrm{w} / \mathrm{v})$ for the $\mathrm{D}(+)$ xylose in the isolation medium. Agar slopes were streaked and stabbed with one loopful of a $24 \mathrm{hr}$. culture of organism $4 \cdot 13$ grown on xylose-rumen liquor + mineral salts agar (hereafter referred to as ' $X$ agar'). Controls were $X$ agar itself and the medium without added D $(+)$ xylose. As soon as 'fair' $(1+)$ growth appeared, the organism was subcultured to a fresh tube of the same medium to obviate 'carry over' effects. In no instance did growth appear in the medium without carbohydrate. Density of growth was estimated as 'fair' $(1+)$ to 'luxuriant' $(4+)$. Immediately following subculture the initial slope was flooded with Lugol's iodine solution and the colour noted. It was considered necessary to do so at the earliest possible moment after growth appeared, since the iodophilic polysaccharide is a reserve substance and is utilized upon continued incubation. Acid, but not necessarily gas formation was detected in this study, since carbonate (which appeared essential for optimal growth) liberated as $\mathrm{CO}_{2}$ by fermentation acids split the agar and produced frothiness in the syneresis water.

\section{Nutritional requirements}

Several workers (Hungate, 1950; McNeill, Doetsch \& Shaw, 1954; Bryant \& Doetsch, 1954a) have shown that factors(s) found in rumen liquor are essential for in vitro cultivation of many authentic rumen bacteria. In addition to studying this point with isolate $4 \cdot 13$, the effect of bicarbonate on growth was 
Table 1. Growth and 'starch' production by Bacteroides amylogenes on various substrates

The concentration of substrate in the agar medium was $1 \%(\mathrm{w} / \mathrm{v})$ unless otherwise stated; it was sterilized separately by Seitz filtration of a concentrated aqueous solution except in the case of polysaccharides of high molecular weight when sterilization was by intermittent steaming. Analar carbohydrates were used wherever possible; the source of the rarer sugars is indicated below.

$$
\begin{aligned}
& \text { Aldopentoses } \\
& \text { D (+) Xylose } \\
& \text { L (-) Xylose (L. Light) } \\
& \text { D (-) Arabinose (L. Light) } \\
& \text { L (+) Arabinose (Kerfoot) } \\
& \text { D (+) Ribose (L. Light) } \\
& \text { D (+) Lyxose (L. Light) } \\
& \text { Methylaldopentoses } \\
& \text { L (+) Rhamnose } \\
& \text { L (-) Fucose (L. Light) }
\end{aligned}
$$

Substrate

Aldohexoses

$\mathrm{p}(+)$ Glucose

$\mathrm{D}(+)$ Mannose (recrystallized from ethanol and methanol)

$\mathrm{D}(+)$ Galactose

Ketohexoses

D (-) Fructose

Sorbose

Sugar alcohols

Glycerol

Adonitol (G. T. Gurr)

Mannitol

Sorbitol

Dulcitol

Inositol

Aminosugar

Glucosamine hydrochloride

Hexose phosphates $(0.5 \%, \mathrm{w} / \mathrm{v})$

Glucose-1-phosphate ( $K$ salt)

Glucose-6-phosphate (K salt)

Disaccharides

Sucrose

Maltose

Lactose

Cellobiose

Trehalose (G. T. Gurr)

Melibiose (L. Light)

Trisaccharide

Raffinose (Kerfoot)

Glycosides

-Methylglucoside (B.D.H.)

Salicin

Aesculin (G. T. Gurr)

Pentosans

Soluble wheat flour pentosan entirely free from hexosan;

(contains xylose and arabinose units, Perlin, 1951)

Soluble xylan of Rhodymenia palmata (Barry \& Dillon, 1940)

\section{Amount of \\ bacterial Iodophilic growth in $(n)$ reaction days of growth}

$4+(1)$

$0 \quad(8)$

$1+(1)$

$4+(1)$

$1+(2)$

0 (5)

$$
\begin{array}{r}
+ \\
0 \\
+ \\
+ \\
+
\end{array}
$$

$4+(1)$

$4+(1)$

$+$

$4+(1)$

$4+(1)$

$4+(1)$

$4+(1)$

0 (8)

$1+(4)$

0 (8)

$0 \quad(6)$

$\begin{array}{ll}0 & (6)\end{array}$

0 (8)

0 (4)

$4+(2)$

$1+(5)$

$1+(2)$

$4+(1)$

$4+(1)$

$1+(4)$

$4+(1)$

$4+(1)$

$4+(1)$

$4+(1)$

0 (8)

$4+(1)$

$4+(1)$

$3+(1)+$

$1+(2)+$ 
Table 1 (cont.)

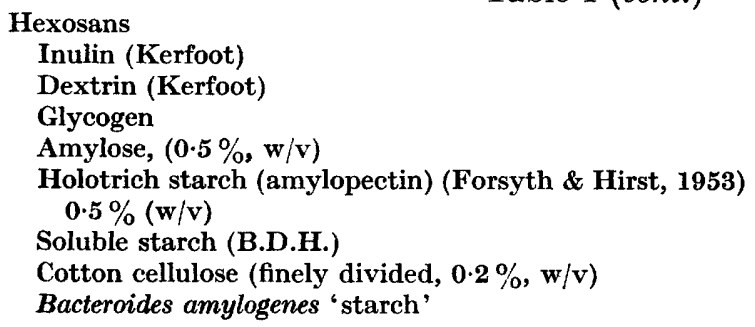

$\begin{array}{ll}4+(1) & + \\ 1+(1) & + \\ 0 \quad(6) & 0 \\ 0 \quad(6) & 0 \\ 0 \quad(6) & 0 \\ 0 \quad(6) & 0 \\ 0 \quad(12) & 0 \\ 0 \quad(6) & 0\end{array}$

Organic acids

The organism did not utilize any of the following: glucuronate, pyruvate, lactate, fumarate, succinate, citrate.

investigated. Substitutions for $\mathbf{4 0} \%(\mathrm{w} / \mathrm{v})$ rumen liquor in $\mathrm{X}$ agar (all given as $\%(\mathrm{w} / \mathrm{v})$ 'Bacto' products) were made as follows: (1) $0.5 \%$ Casitone; (2) $0.5 \%$ Casitone $+0.5 \%$ yeast extract; (3) $0.5 \%$ yeast extract; (4) $0.5 \%$ Tryptose; (5) $0.5 \%$ yeast extract $+0.5 \%$ peptone; (6) same as (1) but $0.066 \mathrm{M}$-phosphate buffer ( $\mathrm{pH} \mathrm{7.0}$ ) added aseptically ( $30 \mathrm{ml}$. in $50 \mathrm{ml}$. medium) without $\mathrm{Na}_{2} \mathrm{CO}_{3}$, and tubed under $\mathrm{N}_{2} ;(7) \mathrm{X}$ agar without $\mathrm{Na}_{2} \mathrm{CO}_{3}$ and tubed under $\mathrm{N}_{2}$; (8) a defined medium composed of the following per $100 \mathrm{ml}$; calcium-D-pantothenate, $0.1 \mathrm{mg}$.; nicotinic acid, $0.25 \mathrm{mg}$.; pteroylglutamic acid, $\mathbf{0 . 0 0 1} \mathrm{mg}$; thiamine hydrochloride, $p$-aminobenzoic acid, pyridoxine hydrochloride and riboflavin, $\mathbf{0} \cdot 1 \mathrm{mg}$. each; inositol, choline chloride, nicotinamide, uracil, guanine hydrochloride, adenine sulphate and xanthine hydrochloride $0.5 \mathrm{mg}$. each; $\mathrm{CoCl}_{2} \cdot 6 \mathrm{H}_{2} \mathrm{O}$ and $\mathrm{CuSO}_{4} .5 \mathrm{H}_{2} \mathrm{O}, 0.15 \mathrm{mg}$. each; $\mathrm{MnSO}_{4} .4 \mathrm{H}_{2} \mathrm{O}, 0.014$ g.; $\mathrm{MgSO}_{4} .7 \mathrm{H}_{2} \mathrm{O}, 0.056$ g.; $\mathrm{FeSO}_{4} \cdot 7 \mathrm{H}_{2} \mathrm{O}, 0.0034$ g.; $n$-valeric acid, 5.0 mg.; iso-valeric acid, $2.5 \mathrm{mg}$.; sodium acetate, $0.41 \mathrm{~g}$., sodium citrate $2 \mathrm{H}_{2} \mathrm{O}, 0 \cdot 2 \mathrm{~g}$., $\mathrm{NH}_{4} \mathrm{Cl}, 0.152$ g., resazurin, $0.5 \mathrm{ml}$. of a $0 \cdot 1 \%(\mathrm{w} / \mathrm{v})$ aqueous solution; agar (Gurr) $1.5 \mathrm{~g} ., \mathrm{D}(+)$ xylose, $1.0 \mathrm{~g}$.; cysteine hydrochloride, $0 \cdot 1 \mathrm{~g}$; $\mathrm{Na}_{2} \mathrm{CO}_{3}, \mathbf{0} \cdot \mathbf{4}$ g. The latter three compounds were Seitz filtered and added aseptically to the medium which was then tubed under $\mathrm{CO}_{2} ;$ (9) same as (8) but with $0.5 \%$ each of yeast extract and proteose-peptone added. The density of growth was compared with that on $\mathrm{X}$ agar after 24 and $48 \mathrm{hr}$. of incubation at $39^{\circ}$, and for longer periods when necessary. Four serial subcultures were made on each medium supporting growth of isolate 4.13 before the observation was recorded.

\section{Factors influencing the utilization of iodophilic polysaccharide}

The growth of isolate $4 \cdot 13$ from 35 tubes of $\mathrm{X}$ agar $\left(44 \mathrm{hr}\right.$. at $\left.39^{\circ}\right)$ was washed off with $0.066 \mathrm{~m}$-phosphate buffer $(\mathrm{pH} 7 \cdot 0$ ). It was found necessary to grow the organism on slopes of solid medium after repeated failure of attempts to obtain good growth quickly in liquid media or on solid medium in Roux bottles. The organisms were washed twice in buffer (no reducing sugar in supernatant) and the optical density adjusted to 0.78 at $640 \mathrm{~m} \mu$. (EEL filter no. 205) with the EEL (Evans Electroselenium Ltd., Harlow, Essex) colorimeter. These suspensions had a protein nitrogen content of usually about 
$0.28 \mathrm{mg} . / \mathrm{ml}$. Suspensions of organisms, adjuncts and buffer were made to a volume of $3 \mathrm{ml}$. in small rubber-stoppered test tubes and incubated under the appropriate $\mathrm{O}_{2}$-free gas in a $39^{\circ}$ water bath. Table 2 is a protocol of the various factors investigated. After 1, 3 and 5 hr. incubation $0.25 \mathrm{ml}$. samples were removed from each tube and the organisms sedimented with an M.S.E. angle centrifuge. The sediment was washed once in buffer and the organisms suspended in a final volume of $2 \mathrm{ml}$. One-tenth ml. iodine solution (aqueous solution of $\left.2 \%(\mathrm{w} / \mathrm{v}) \mathrm{KI}+\mathbf{0} \cdot 2 \%(\mathrm{w} / \mathrm{v}) \mathrm{I}_{2}\right)$ was added with thorough mixing, and the optical density read on the EEL colorimeter against a boiled-cell control arbitrarily set at $0 . D .=1 \cdot 00$. The rate of disappearance of the blue colour was taken as a measure of polysaccharide utilization and the limiting optical density upon depletion was between $0 \cdot 5$ and $0 \cdot 6$.

\section{End products of xylose fermentation}

Several workers (Heald, 1952; Doetsch, Robinson, Brown \& Shaw, 1953; Howard, 1955) have observed that mixed suspensions of rumen bacteria do not produce lactic acid from pentoses. To determine whether this held for isolate $4 \cdot 13$, and to note whether fatty acids characteristic of rumen liquor were produced from $\mathbf{D}(+)$ xylose fermentation, a liquid medium was devised which allowed fairly good if slow growth. The medium had the following composition: $0.5 \%(\mathrm{w} / \mathrm{v})$ yeast extract, $0.5 \%(\mathrm{w} / \mathrm{v})$ proteose-peptone, $10 \%(\mathrm{v} / \mathrm{v})$ strained rumen liquor, $7.5 \%(\mathrm{v} / \mathrm{v})$ of each of Hungate's mineral salt solutions, $0 \cdot 1 \%(\mathrm{v} / \mathrm{v})$ of a $0 \cdot 1 \%(\mathrm{w} / \mathrm{v})$ aqueous resazurin solution, $1.0 \%(\mathrm{w} / \mathrm{v}) \mathrm{D}(+)$ xylose, $0.1 \%(\mathrm{w} / \mathrm{v})$ cysteine hydrochloride, and $0.4 \%$ $(\mathrm{w} / \mathrm{v}) \mathrm{Na}_{2} \mathrm{CO}_{3}$. The latter three compounds were sterilized by Seitz filtration and added aseptically to the autoclaved medium. Inoculum was one ml. of the complete medium used to wash off the growth from a 24 hr. culture of isolate 4.13 on X agar. Duplicate flasks ( $150 \mathrm{ml}$. volume filled two-thirds full) were set up, one incubated for a week at $39^{\circ}$ and the other stored at $2^{\circ}$. At the end of the incubation period residual carbohydrate was determined by the method of Somogyi (1945), lactic acid by the Barker \& Summerson (1941) method, and fatty acids by the method of James \& Martin (1952).

\section{Purification and characterization of iodophilic polysaccharide}

Growth from 500 slope cultures of isolate $4 \cdot 13$ grown for $44 \mathrm{hr}$. on $\mathrm{X}$ agar at $39^{\circ}$ was washed off with $0.066 \mathrm{M}$-phosphate buffer $(\mathrm{pH} 7 \cdot 0)$ and twice filtered through 1 in. layers of closely packed glass wool. The organisms were washed twice in buffer and suspended in a minimal (1-3 ml.) amount of buffer. Reducing sugars were absent from the supernatant fluids of these washings. The resulting bacterial paste was kept at $-20^{\circ}$ until the extraction process was begun. The method used was that of Hobson \& Mann (1955).

Sixteen g. cell paste (wet wt.) were ground in a cold mortar with 32 g. cold, acid-washed, acetone-extracted carborundum (grade F) [Griffin \& Tatlock, Ltd., London] for $15 \mathrm{~min}$. and the mass twice extracted with $33 \%(\mathrm{w} / \mathrm{v})$ chloral hydrate at $80^{\circ}$. The extract was filtered through a sintered glass filter 
(grade 5) and the filtrate slowly added with stirring to 4 vol. cold acetone. After standing $24 \mathrm{hr}$. at $2^{\circ}$ the precipitated polysaccharide was collected by centrifugation and dried by trituration first with acetone and then with ether (yield $320 \mathrm{mg}$.). One hundred $\mathrm{mg}$. of crude polysaccharide powder was wetted with ethanol and dissolved in $0 \cdot 1 \mathrm{~N}-\mathrm{NaOH}$ by heating in a boiling water bath for several minutes. The resulting suspension was neutralized to the phenolphthalein end point and to $50 \mathrm{ml}$. of liquor was added $2 \mathrm{~g}$. hydrated sodium acetate, $10 \mathrm{ml}$. chloroform and $1 \mathrm{ml} . n$-butanol. After shaking for $10 \mathrm{~min}$. in a separating funnel, the aqueous layer was removed and dialysed against running distilled water for 3 days. The non-diffusing polysaccharide was precipitated by 2 vol. cold ethanol, allowed to stand for $24 \mathrm{hr}$. at $2^{\circ}$, centrifuged and dried by grinding in ethanol and finally in ether. The resulting powder was dried in vacuo over $\mathrm{P}_{2} \mathrm{O}_{5}$. The purified polysaccharide $(3.5 \mathrm{mg}$.) was hydrolysed in $0.5 \mathrm{ml}$. of $2 \mathrm{~N}-\mathrm{H}_{2} \mathrm{SO}_{4}$ in a sealed tube at $100^{\circ}$ for $2 \mathrm{hr}$. and neutralized with $\mathrm{BaCO}_{3}$. Constituent monosaccharides were detected by descending paper chromatography using: (a) n-butanol:pyridine:water (10:3:3); (b) ethyl acetate:pyridine:water $(10: 4: 3) ;(c) n$-butanol:glacial acetic acid:water $(4: 1: 5)$. Aniline phosphate $(0.05 \mathrm{M})$ was the developing agent in each instance. Reference carbohydrates were $\mathbf{D}(+)$ glucose, $\mathbf{D}(+)$ xylose, $\mathbf{L}(+)$ arabinose, $\mathbf{D}(+)$ galactose and $\mathbf{L}(+)$ rhamnose. 'Starch' content was assayed by estimating reducing sugar as glucose (Somogyi, 1945), blue value was determined by the method of Hobson \& MacPherson (1952), ash by ignition, and total nitrogen by the micro-Kjeldahl method.

\section{RESULTS}

\section{Characterization of the organism}

Isolate $4 \cdot 13$ is a Gram-negative curved rod most closely allied to Bacteroides. Hereafter it will be referred to as Bacteroides amylogenes n.sp., whose characteristics are the following:

Bacteroides amylogenes n.sp. is a Gram-negative, non-motile, non-flagellated, asporogenous, non-capsulated, anaerobic, iodophilic, curved rod $(2.5 \mu$. long by $0.5 \mu$. wide) from the rumen of a sheep (Pl. 1, fig. 1). It occurs singly and in short chains of organisms superficially resembling spirilla. The organisms are quite fragile and crush easily when pressed between glass slides. The organism is mesophilic and grows best at $39^{\circ}$, slowly at $32^{\circ}$, and not at all at $22^{\circ}$ or $55^{\circ}$. Colonies on $\mathbf{X}$ agar are small (1-2 mm.), circular, raised, mucoid and pearl white. Twenty-four to forty-eight hr. colonies stain purple to blue black when covered with Lugol's iodine solution (Pl. 1, fig. 2) and organisms from these colonies are uniformly purple (PI. 1, fig. 3). Rumen liquor or other complex nitrogenous nutrient, bicarbonate and a fermentable carbohydrate are needed for good in vitro growth. The organism ferments $\mathrm{D}(+)$ xylose, $\mathrm{L}(+)$ arabinose, $\mathrm{L}(+)$ rhamnose, $\mathrm{L}(-)$ fucose, $\mathrm{D}(+)$ glucose, $\mathrm{D}(+)$ mannose, $\mathrm{D}(+)$ galactose, $\mathrm{D}(-)$ fructose, glucosamine hydrochloride, sucrose, maltose, lactose, cellobiose, trehalose, melibiose, raffinose, salicin, aesculin and soluble pentosans with the production of acid and an intracellular iodophilic poly- 
saccharide. It does not ferment $\mathrm{L}(-)$ xylose, $\mathrm{D}(+)$ lyxose, sorbose, adonitol, sorbitol, mannitol, dulcitol, inositol, $\alpha$-methyl-glucoside, glycogen, amylose, soluble starch or cellulose. $\mathrm{H}_{2} \mathrm{~S}$ is produced from cysteine hydrochloride. Indole not formed. Catalase-negative.

Although Bacteroides amylogenes possesses a distinct cell wall when stained by Robinow's (1945) method, it appeared to bend and flex to and fro when observed in capillary tube preparations. This motion did not result in motility or physical progress as far as could be determined. The organism is obligately anaerobic and fails to grow in the absence of suitable reducing agents (as $0 \cdot 1 \%(\mathrm{w} / \mathrm{v})$ cysteine hydrochloride), or when the resazurin indicator is pink to any degree. It survived 5 days of exposure to atmospheric oxygen, and subcultures so treated grew readily upon incubation under anaerobic conditions. Examination of stained preparations made from tubes in which the resazurin indicator showed a trace of oxygen present revealed long festoons and strands of organisms, many possessing 'bulbs' (Pl. 1, fig. 4) typical of those described by Hughes (1956). Probably these are pathological manifestations elicited by growth in the presence of inhibitory amounts of oxygen. Subculture and incubation of these forms under anaerobic conditions resulted in cells of 'regular' morphology.

\section{Polysaccharide formation and utilization studies}

The data in Table 1 reveal that a number of compounds, all carbohydrates, are transformed to iodophilic polysaccharide. It should be emphasized that in every case of growth iodophilic polysaccharide was produced. Notable among compounds not supporting growth were sugar alcohols, dicarboxylic acids, and hexosans except inulin, and to a lesser extent, dextrin. Soluble pentosans were readily fermented, whereas holotrich starch (Forsyth \& Hirst, 1953) and purified Bacteroides amylogenes polysaccharide were not fermented. The pentoses are of some interest, particularly since $\mathrm{C}_{5}$ units must be degraded and resynthesized to the $\mathrm{C}_{6}$ units of the polysaccharide (see below). $\mathrm{D}(+)$ Lyxose, a pentose not found in nature, and $\mathrm{L}(-)$ xylose were not fermented; and $\mathrm{D}(-)$ arabinose and $\mathbf{D}(+)$ ribose supported only fair $(1+)$ growth, yet these colonies were intensely iodophilic.

Bacteroides amylogenes grew poorly $(2+$ at best) on the first eight media listed under 'nutritional requirements'. Medium 9 supported growth equal to that obtained on $\mathbf{X}$ agar. It is significant that this organism did not grow well $(2+)$ on $\mathrm{X}$ agar without bicarbonate (medium 7 ), and not at all on defined medium 8.

In Table 2 is shown the result of a typical experiment on the effect of various factors on the utilization of stored iodophilic polysaccharide by Bacteroides amylogenes. It was found to be readily utilized in $0.066 \mathrm{~m}$-phosphate buffer $(\mathrm{pH} 7 \cdot 0)$ under $\mathrm{N}_{2}$, and the addition of $1 \%(\mathrm{w} / \mathrm{v}) \mathrm{D}(+)$ xylose or $\mathrm{D}(+)$ glucose did not retard the process. In fact, after $5 \mathrm{hr}$. at least $95 \%$ of the added carbohydrate remained unused. Utilization was virtually nil in 0.066 M-phosphate buffer at $\mathrm{pH} 5.0$ under $\mathrm{N}_{2}$, or in 'tris' (tris-(hydroxymethyl)-aminomethane), $\mathrm{pH} \mathbf{7 \cdot 3}$, under $\mathrm{N}_{2}$, and it was noticeably retarded 
in 0.04 M-carbonate + bicarbonate buffer $(\mathrm{pH} \mathrm{7.0})$ in air. Addition of Casitone, acid hydrolysed casein, or strained rumen liquor was without effect, and there was no appreciable depletion of polysaccharide in the boiled cell preparation during $5 \mathrm{hr}$.

Table 2. Utilization of iodophilic polysaccharide under various test conditions

Each tube had a final volume of $3.0 \mathrm{ml}$, including cell suspension (0.28 mg. $\mathrm{N} / \mathrm{ml}$.) adjunct and buffer under appropriate $\mathrm{O}_{2}$-free atmosphere at $39^{\circ}$. All zero $\mathrm{hr}$. readings were o.D. $=1.00$ at $640 \mathrm{~m} \mu$.

\begin{tabular}{|c|c|c|c|c|c|c|}
\hline \multirow[b]{2}{*}{ Buffer } & \multirow[b]{2}{*}{$\mathbf{p H}$} & \multirow{2}{*}{$\begin{array}{l}\text { Atmo- } \\
\text { sphere }\end{array}$} & \multirow[b]{2}{*}{ Adjunct or treatment } & \\
\hline & & & & (1) & (3) & (5) \\
\hline $0.04, \mathrm{M}-\mathrm{HCO}_{3}^{-}$ & $7 \cdot 0$ & $\mathrm{CO}_{2}$ & - & 0.95 & 0.90 & 0.87 \\
\hline $0.1 \mathrm{M}$ 'tris' & $7 \cdot 3$ & $\mathbf{N}_{2}$ & - & 0.97 & 0.96 & 0.95 \\
\hline $0.066 \mathrm{M}^{-\mathrm{PO}_{4}}$ & $5 \cdot 0$ & $\mathbf{N}_{2}$ & - & 0.97 & 0.97 & 0.97 \\
\hline \multirow[t]{4}{*}{$0.066 \mathrm{M}-\mathrm{PO}_{4}$} & $7 \cdot 0$ & $\mathbf{N}_{2}$ & Cells boiled $3 \mathrm{~min}$. & 0.98 & 0.98 & 0.97 \\
\hline & & Air & - & 0.98 & 0.94 & $0 \cdot 92$ \\
\hline & & $\mathbf{N}_{2}$ & $0 \cdot 3 \%(w / v)$ Casitone & - & $0 \cdot 74$ & $0 \cdot 70$ \\
\hline & & $\mathbf{N}_{2}$ & $\begin{array}{l}0.3 \%(w / v) \text { acid hydrolysed } \\
\text { casein }\end{array}$ & - & $0 \cdot 72$ & 0.71 \\
\hline \multirow[t]{4}{*}{$0.066 \mathrm{M}-\mathrm{PO}_{4}$} & $7 \cdot 0$ & $\mathbf{N}_{2}$ & $\begin{array}{l}0 \cdot 3 \%(w / v) \text { strained rumen } \\
\text { liquor }\end{array}$ & - & $0 \cdot 72$ & 0.72 \\
\hline & & $\mathbf{N}_{2}$ & $1.0 \%(w / v) D(+)$ xylose & $0 \cdot 87$ & $0 \cdot 71$ & $0 \cdot 61$ \\
\hline & & $\mathbf{N}_{2}$ & $1.0 \%(w / v)$ D $(+)$ glucose & $0 \cdot 87$ & $0 \cdot 68$ & $0 \cdot 68$ \\
\hline & & $\mathbf{N}_{2}$ & - & $0 \cdot 86$ & $0 \cdot 77$ & $0 \cdot 67$ \\
\hline
\end{tabular}

\section{$X y l o s e$ fermentation and polysaccharide identification}

In Table 3 are shown the products of $\mathrm{D}(+)$ xylose fermentation by Bacteroides amylogenes. These results indicate that $1.7 \%$ of the carbon fermented can be accounted for in lactic acid, and $89 \%$ in the volatile fatty acid fraction

Table 3. Products of xylose fermentation by Bacteroides amylogenes

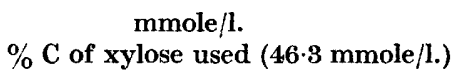

$\begin{array}{cccc}\text { Acetic } & \text { Propionic } & \text { Butyric } & \text { Lactic } \\ 18 \cdot 6 & 5 \cdot 3 & 38 \cdot 6 & 1 \cdot 3 \\ 16 \cdot 1 & 6 \cdot 9 & 66.7 & 1 \cdot 7 \\ 91 \cdot 4 \%\end{array}$

the chief constituent of which is butyric acid. A typical analysis of the intracellular polysaccharide on a dry weight basis was: $[\alpha]_{\mathrm{D}}^{28}=+178^{\circ}(c=0.432$ in $50 \%$ (w/v) $\mathrm{CaCl}_{2}$ solution); 'starch' content, $89 \%$ after acid hydrolysis; blue value $11 \cdot 6$ colorimeter units; total nitrogen, $0 \cdot 1 \%$; ash nil. The only sugar found in the acid hydrolysate by paper chromatography was glucose. At pH 6 and $37^{\circ}$ the extracted polysaccharide was readily hydrolysed by the freeze-dried bacterial $\alpha$-amylase prepared from a rumen streptococcus by Hobson \& MacPherson (1952). 


\section{DISCUSSION}

Species of the genus Bacteroides are not uncommonly found associated with the intestinal tract of mammals. Hungate (1950) and Bryant \& Burkey (1953) described $B$. succinogenes as an important cellulolytic organism of the bovine rumen. In so doing, the characterization of the genus Bacteroides, hitherto described mainly in terms of pathological processes and medical diagnostic bacteriology (Bergey's Manual, 1948), was extended to include cellulolysis and the production of characteristic end products therefrom. Additional work by Bryant \& Doetsch $(1954 a, b)$ established some of the nutritional requirements of $\boldsymbol{B}$. succinogenes. The organism studied in the present work has properties which most closely ally it to the rumen Bacteroides spp. group, i.e. it is a Gramnegative, non-flagellated, asporogenous, curved rod with rounded ends. Although it cannot hydrolyse cellulose and is iodophilic, it does attack soluble pentosans (hemicelluloses), requires bicarbonate, factors in rumen liquor and a fermentable carbohydrate for in vitro proliferation. It produces end products typical of those found in normal rumen liquor from a variety of carbohydrates. Bryant \& Burkey (1953) isolated many strains of bacteria from the bovine rumen which were similar to the 'less actively cellulolytic rod' of Hungate (1950). Many of their strains failed to attack cellulose even after prolonged incubation. Huhtanen \& Gall (1953) also isolated Gram-negative curved rods similar to those of Hungate. It is interesting to note that some of Hungate's cellulolytic isolates were considered to migrate through agar in a manner similar to the cytophagas but he could not observe any creeping or bending movement. B. amylogenes is clearly flexible when examined in capillary tube preparations or when the phase microscope is used.

Despite similarities and differences of the rumen Bacteroides spp. group previously described and $\boldsymbol{B}$. amylogenes, it is emphasized that the taxonomic assignment is purely provisional. It is possible that another, more suitable, place may be found. It might be contended that $B$. amylogenes be considered with the genus Desulphovibrio. Lewis (1954) found that sulphate reduction in the rumen occurs rapidly and suggested that species of this genus might be involved. However, absence of flagella and apparent failure to reduce inorganic sulphate to $\mathrm{H}_{2} \mathrm{~S}$ argue against this consideration. Great difficulty is encountered in attempting to classify bacteria from unique environments (as the rumen), using a system wherein generic descriptions are based mainly on medically important members. Yet, it is probably better to assign names to isolates, however tentative, rather than apply taxonomically meaningless letters or numbers to them.

The bicarbonate requirement of Bacteroides amylogenes is consistent with observations of Hungate (1950) and Bryant \& Burkey (1953). Although the nutritional requirements of $B$. amylogenes ' were not studied systematically it is probable that some of the unknown factors supplied by rumen liquor are to be discovered among the constituents of medium 8. Yeast extract and proteosepeptone alone, or the completely defined medium alone, do not support good growth, whereas they do so when in combination. $\mathbf{X}$ agar, a medium in which 
the only non-defined constituent is rumen liquor, likewise supports luxuriant growth. Obviously the factors required are in rumen liquor, an observation made by Hungate (1950) and Bryant \& Doetsch (1954a). In general, it appears that commercially available peptones, usually adequate for cultivation of nutritionally fastidious bacteria, do not contain all the growth factors required for adequate in vitro growth of many authentic rumen bacteria. McNeill et al. (1954) came to this conclusion after a study of the nutritional requirement of the total rumen bacterial population. Wilson \& Briggs (1955) have been unable to confirm this and found 'reinforced clostridial medium' of Hirsch \& Grinsted (1954) a satisfactory replacement for rumen liquor.

The foregoing studies suggest that certain purely physiological criteria might be advanced for judging the authenticity of a bacterium isolated from the rumen. These would include: (1) optimum temperature about $39^{\circ} ;(2)$ ability to grow anaerobically and consequently a need for some reducing agent in media devised for in vitro cultivation; (3) requirement for some organic factor for in vitro growth, the factor to be found in rumen liquor and not necessarily in commercially available peptones; (4) production of fatty acids from amino acids and carbohydrates, these to be characteristic of those found in normal rumen liquor. Undoubtedly other conditions can be added as work progresses.

Bacteroides amylogenes survived 5 days in the presence of atmospheric $\mathrm{O}_{2}$. It did not grow under these conditions, but did so promptly when subcultured and incubated anaerobically. There are reports in the literature stressing elaborate precautions taken to exclude the atmosphere from rumen liquor samples. It would appear that they are largely unnecessary. Oxygen may be inhibitory to authentic rumen bacteria; it is very doubtful whether it is lethal (Doetsch et al. 1952). The transfer of the rumen bacterial flora from mature animal to young must of necessity proceed through space containing oxygen, and it is likely that such organisms suspended in rumen liquor are adequately protected from any ill-effects of atmospheric $\mathrm{O}_{2}$ by reducing substances contained therein.

Bacteroides amylogenes can transform into " starch' a portion of any compound which serves as an energy source (Table 1). In this regard it is unlike iodophilic strains of Streptococcus bovis (Hobson \& Mann, 1955) which produce iodophilic polysaccharide only from a very limited range of carbohydrates. Iodophilic polysaccharide also is produced from many carbohydrates by mixed suspensions of bovine rumen bacteria (Robinson et al. 1955). The transformation of energy sources to polysaccharide is an important but not exclusive characteristic of many authentic rumen bacteria. The reaction may represent a mechanism, developed during the evolution of the rumen bacterial flora, for dealing with an excess of soluble fodder carbohydrate.

The 'starch' is a reserve substance which is used during starvation periods. The utilization of this internal polysaccharide (probably via a phosphorylase, but not excluding a non-diffusible amylase) proceeds even in the presence of exogenous soluble carbohydrates. Either additional factors are required or conditions under which the experiments are performed prevent the utilization 
of them. In any event, mixed suspensions of rumen bacteria readily utilize exogenous soluble carbohydrate and 'spare' their internal polysaccharide, or add to it (Gibbons et al. 1955) when continuous growth is not possible. Bacteroides amylogenes, in resting suspensions, does not produce polysaccharide even when its internal supply is depleted. Depletion requires $3-5 \mathrm{hr}$. at $39^{\circ}$ in a resting suspension, a period of time which perhaps leaves the organisms moribund.

The reserve polysaccharide of Bacteroides amylogenes is typical of those so far described for authentic rumen organisms, i.e. it is composed solely of glucose units. It may be emphasized that all known intracellular, as distinct from capsular polysaccharides, are glucose polymers (Oxford, 1951; Gibbons et al. 1955; Hobson \& Mann, 1955). The good yield of polysaccharide in this instance was due to the relatively large quantities of 'starch' stored as well as the ease with which the organisms can be ruptured.

In line with the above criteria for establishing the authenticity of a bacterium isolated from the rumen, it is of interest to note that the end products from $D(+)$ xylose fermentation are typical of compounds found in rumen liquor. The negligible lactic acid production by Bacteroides amylogenes was not unexpected since other pentose-fermenting rumen bacteria do not produce this metabolite from pentoses (Heald, 1952; Doetsch et al. 1953). It should be borne in mind, that organisms other than the lactic acid bacteria may be responsible for the occasional traces of lactic acid found in normal rumen liquor, or the large amounts found in abnormal rumen liquor.

The work of one of the authors (R.N.D.) was made possible through grants of the John Simon Guggenheim Memorial Foundation and the University of Maryland. He is particularly indebted to the Director of the Rowett Research Institute, Dr D. P. Cuthbertson for his kind hospitality, and to Drs P. N. Hobson and R. J. Pennington for advice on the polysaccharide extraction and purification and on fatty acid analysis respectively.

\section{REFERENCES}

Barker, S. B. \& Summerson, W. H. (1941). The colorimetric determination of lactic acid in biological material. J. biol. Chem. 138, 536.

Barry, V. C. \& Dillon, T. (1940). Occurrence of xylans in marine algae. Nature, Lond. 146, 620.

Bergey's Manual of Determinative Bacteriology (1948). Ed. Breed, R. S., Murray, E. G. \& Hitchens, A. P., 6th ed. Baltimore, Md.: Williams and Wilkins.

Bryant, M. P. \& Burkey, L. A. (1953). Cultural methods and some characteristics of some of the more numerous groups of bacteria in the bovine rumen. J. Dairy Sci. 36, 205.

Bryant, M. P. \& Doetsch, R. N. (1954a). A study of actively cellulolytic rodshaped bacteria of the bovine rumen. J. Dairy Sci. 37, 1176.

Bryant, M. P. \& Doetsch, R. N. (1954b). Factors necessary for growth of Bacteroides succinogenes in the volatile acid fraction of rumen fluid. Science, 120, 944.

Doetsch, R. N., Robrnson, R. Q. \& Shaw, J. C. (1952). Techniques employed in cultural investigations of the bacteriology of bovine rumen contents. J. Anim. Sci. 11, 536. 
Doetsch, R. N., Robinson, R. Q., Brown, R. E. \& Shaw, J. C. (1953). Catabolic reactions of mixed suspensions of bovine rumen bacteria. J. Dairy Sci. 36, 825.

EADIE, J. M. \& OXFond, A. E. (1955). Factors involved in the production of a novel kind of derangement of storage mechanism in living holotrich ciliate protozoa from sheep rumen. J. gen. Microbiol. 12, 298.

Fisher, P. J. \& Conn, J. E. (1942). A flagella staining technic for soil bacteria. Stain Tech. 17, 117.

Forsyth, G. \& Hirst, E. L. (1953). Protozoal polysaccharides. Structure of the polysaccharide produced by the holotrich ciliates present in sheep's rumen. J. chem. Soc. p. 2132.

Grbbons, R. J., Doetsch, R. N. \& Shaw, J. C. (1955). Further studies on polysaccharide production by bovine rumen bacteria. J. Dairy Sci. 38, 1147.

Heald, P. J. (1952). The fermentation of pentoses and uronic acids by bacteria from the rumen contents of sheep. Biochem. J. 50, 503.

Hirsch, A. \& Grinsted, E. (1954). Methods for the growth and enumeration of anaerobic spore-formers from cheese, with observations on the effect of nisin. J. Dairy Res. 21, 101.

Hobson, P. N. \& MacPherson, M. J. (1952). Amylases of Clostridium butyricum and a Streptococcus isolated from the rumen of the sheep. Biochem. J. 52, 671.

Hobson, P. N. \& ManN, S. O. (1955). Some factors affecting the formation of iodophilic polysaccharide in Group D streptococci from the rumen. J. gen. Microbiol. 13, 420.

Howard, B. H. (1955). Ruminal fermentation of pentosan. Biochem. J. 60, i.

Hughes, W. H. (1956). The structure and development of the induced long forms of bacteria. In Bacterial Anatomy, 6th Symp. Soc. gen. Microbiol. Cambridge University Press.

Huhtanen, C. N. \& Gall, L. S (1953). Rumen organisms. I. Curved rods and a related rod type. $J$. Bact. 65,548 .

Hungate, R. E. (1950). The anaerobic mesophilic cellulolytic bacteria. Bact. Rev. $14,1$.

JAMES, A. T. \& MARTin, A. J. P. (1952). Gas liquid partition chromatography: the separation and micro-estimation of volatile fatty acids from formic acid to dodecanoic acid. Biochem. J. 50, 679.

Leirson, E. (1951). Staining, shape, and arrangement of bacterial flagella. J. Bact. 62, 377 .

LEwrs, D. (1954). The reduction of sulphate in the rumen of the sheep. Biochem. $J$. 56, 391.

MaNn, S. O. \& Oxford, A. E. (1955). Relationships between viable saccharolytic bacteria in rumen and abomasum of the young calf and kid. J. gen. Microbiol. $12,140$.

McNeill, J. J., Doetsch, R. N. \& Shaw, J. C. (1954). Some nutritional requirements of bovine rumen bacteria. J. Dairy Sci. 37, 81.

Morr, R. J. \& Masson, M. J. (1952). An illustrated scheme for the microscopic identification of the rumen microorganisms of sheep. J. Path. Bact. 64, 343.

Oxford, A. E. (1951). Conversion of certain soluble sugars to a glucosan by holotrich ciliates in the rumen of the sheep. J. gen. Microbiol. 5, 83.

Perlin, A. S. (1951). Isolation and composition of the soluble pentosans of wheat flours. Cereal Chem. 28, 370.

Plimmer, H. J. \& Paine, S. G. (1921). A new method for the staining of bacterial flagella. J. Path. Bact. 24, 286.

Rosinow, C. F. (1945). Nuclear apparatus and cell structure of rod-shaped bacteria. In Bacterial Cell, Cambridge, Mass. : Harvard University Press.

Robinson, R. Q., Doetsch, R. N., Sirotnak, F. M. \& Shaw, J. C. (1955). Production of lactic acid and an iodine staining substance by bovine rumen bacteria. J. Dairy Sci. 38, 13. 
Somogyi, M. (1945). A new reagent for the determination of sugars. J. biol. Chem. $160,61$.

Wilson, M. K. \& Briggs, C. A. E. (1955). The normal flora of the bovine rumen. II. Quantitative bacteriological studies. J. appl. Bact. 18, 294.

\section{EXPLANATION OF PLATE}

Fig. 1. Crystal violet stain of $20 \mathrm{hr}$. culture grown on $\mathrm{X}$ agar. $\times 880$.

Fig. 2. Colonies of $20 \mathrm{hr}$. culture grown on $X$ agar and covered with Lugol's iodine solution. $\times 2$.

Fig. 3. Wet preparation of Lugol's iodine-treated cells taken from $20 \mathrm{hr}$. culture grown on $\mathrm{X}$ agar. $\times 880$.

Fig. 4. Long forms and 'bulbs' produced in presence of toxic amounts of oxygen. $\times 850$.

(Received 25 July 1956) 
Journal of General Microbiology, Vol. 16, No. 1

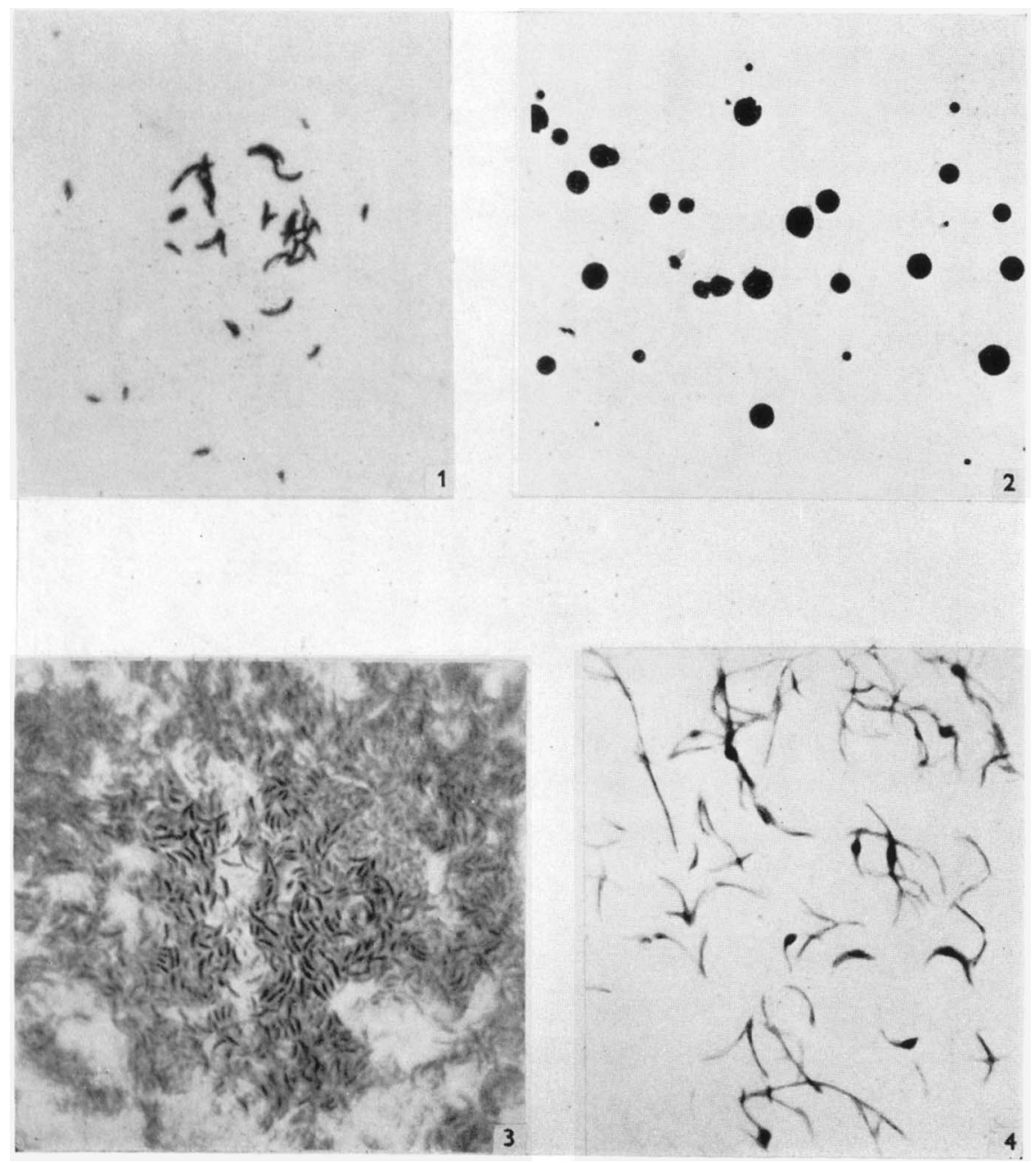

R. N. Doetsch, B. H. Howari, S. O. Mann and A. E. Oxford-Poiysaccharide

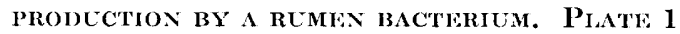

(Facing p. 168) 